\title{
Secondary cluster headache and numb chin syndrome as initial manifestation of high-grade B-lymphoma: a case report
}

\author{
Joe Munoz-Cerón ${ }^{1,2^{*}} \mathbb{D}$, Felipe Díaz-Forero ${ }^{1}$, Adriana Buitrago ${ }^{3}$ and Sandra Chinchilla ${ }^{4}$
}

\begin{abstract}
Background: Cluster headache is a primary condition characterized by severe headache accompanied by trigeminal autonomic signs. By definition, it is not attributed to underlying etiologies; however, under certain clinical characteristics, secondary etiologies must be ruled out.

Case presentation: We present the case of a 48-year-old Hispanic man with a history of episodic right orbital pain, lasting 30 minutes, associated with ipsilateral tearing, who prior to the onset of his symptoms reported loss of appetite, weight loss, and paresthesias in the right chin region. After work-up studies, high-grade lymphoma with infiltration to the right submental nerve was diagnosed, in which numb chin syndrome was the initial presentation. Despite initiation of treatment, the patient died 3 weeks after the diagnosis.
\end{abstract}

Conclusions: In the study of cluster headache, underlying etiologies must be considered when there are atypical clinical manifestations. Within these etiologies, metastases to pericranial nerves must be included, which, besides generating localized symptoms, can activate the trigeminal vascular system simulating headaches of primary etiology.

Keywords: Cluster headache, Lymphoma, Etiologies, Secondary headache, Cancer

\section{Background}

Although by definition cluster headache is a primary entity, its clinical approach includes ruling out secondary etiologies. Based on the classification scheme of the International Headache Society, secondary etiologies of vascular origin, nonvascular intracranial causes by cerebrospinal fluid flow disorders and by neoplastic lesions have been described [1-3].

Although cases related to the compromise of other cranial structures such as the sinuses and the ocular region have been reported [4], there are no descriptions of cases, to the best of our knowledge, in which cranial involvement by pericranial nerve compromise is demonstrated

*Correspondence: joemunoz@centrodolordecabeza.com

1 Present Address: Departamento de Neurologia, Hospital Univesitario Mayor MEDERI - Universidad del Rosario, Bogotá, Colombia

Full list of author information is available at the end of the article in the context of systemic diseases. We report a case in which high-grade lymphoma with invasion to the submental nerve was diagnosed, with a manifestation of numb chin syndrome and symptomatic cluster headache.

\section{Case presentation}

A Hispanic 48-year-old man referred to the specialized headache consultation for diagnosis of cluster headache, which did not obtain improvement of symptoms after treatment with oxygen at $10 \mathrm{~L}$ per minute, verapamil $240 \mathrm{mg}$, topiramate $100 \mathrm{mg}$ per day, and bilateral occipital block with lidocaine $2 \%$ without epinephrine. In our assessment, we found a 4-month history of high-severity, 30-minute right orbital pain episodes associated with ipsilateral tearing without residual pain, as often as two to eight attacks per day; precipitating factors were not identified. There was no history of headache prior to the referred period, and no smoking or alcohol consumption. original author(s) and the source, provide a link to the Creative Commons licence, and indicate if changes were made. The images or other third party material in this article are included in the article's Creative Commons licence, unless indicated otherwise in a credit line to the material. If material is not included in the article's Creative Commons licence and your intended use is not permitted by statutory regulation or exceeds the permitted use, you will need to obtain permission directly from the copyright holder. To view a copy of this licence, visit http://creativecommons.org/licenses/by/4.0/. The Creative Commons Public Domain Dedication waiver (http://creativeco mmons.org/publicdomain/zero/1.0/) applies to the data made available in this article, unless otherwise stated in a credit line to the data. 
The psychosocial and family history was irrelevant. In this evaluation, there was also a documented report of paresthesias in the right submental region together with reports of 8-pound weight loss attributed by the patient to a decrease in food intake since the beginning of the headache episodes. The general physical examination showed slight induration in the gingival region corresponding to the territory of the right submental nerve; the neurological exploration was within normal limits.

Due to the refractoriness of the symptoms along with previous Magnetic resonance imaging (MRI), Magnetic resonance angiography (MRA), Magnetic resonance venography (MRV), and Cerebro spinal fluid (CSF) studies within normal limits in addition to weight loss, it was considered to rule out underlying systemic etiologies with neurological manifestations. F-2-fluoro-2-deoxyD-glucose positron emission tomography (18F-FDGPET) was then performed, which demonstrated findings suggestive of disseminated metastatic disease with predominance in the gastric region, affecting right mandibular region plus multiple foci in the cranial region (Fig 1). Due to the predominant gastric involvement, the patient was referred to gastroenterology where an endoscopy of digestive tract was performed, of which leather bottle stomach was reported with histology study of high-grade B-cell lymphoma. This finding matched the result of biopsy performed in the right submental nerve over the induration area reported at our service admission (Fig 2). After the excisional biopsy on the mental nerve, the pain episodes disappeared, leaving a hypoesthetic area in the corresponding territory. After the above-described clinical analysis, the diagnosis of cluster headache and numb chin syndrome secondary to B-cell lymphoma stage 4B was considered. Despite initiation of treatment, the patient died 3 weeks after the diagnosis.

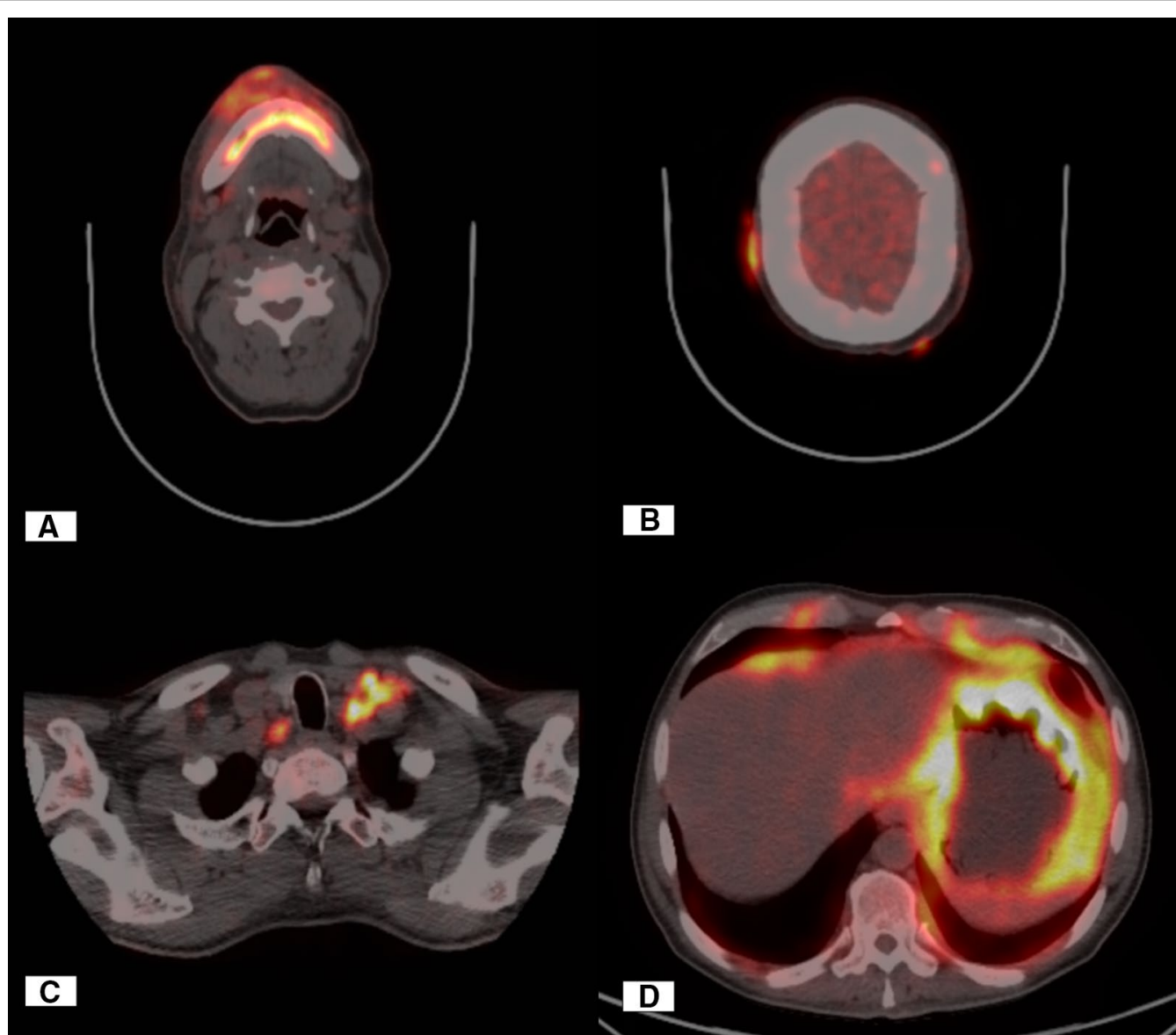

Fig. 1 Images (18F-FDG-PET). A Hypermetabolic zone in soft tissues of the right lower jaw region, plus the ipsilateral submental nerve. B Hypermetabolic nodular lesions of subcutaneous location in the bilateral parietal region. C Hypermetabolic lesions suggestive of nodular cluster of the left internal jugular chain and right paratracheal adenopathy. D Axial image of abdomen with distended stomach. Thickening of the gastric wall is observed, which presents major metabolism throughout it 

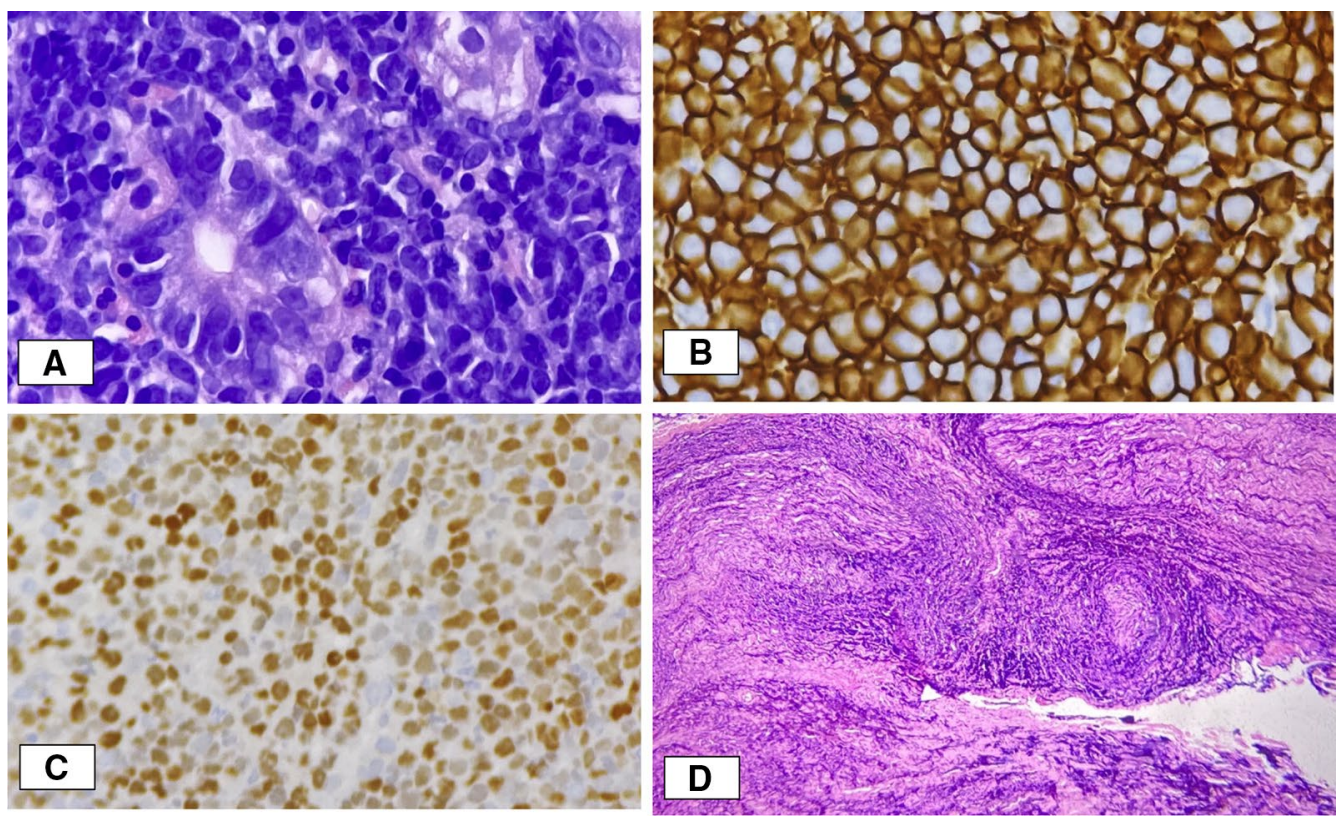

Fig. 2 Histopathological findings. A [40x, hematoxylin and eosin (HE)]. Gastric mucosa with lymphoid neoplasm consisting of intermediate to large cells with scant cytoplasm arranged in a diffuse pattern. B $(40 \times$, immunohistochemistry). The neoplastic cells show immunoreactivity for CD20. C (40x, immunohistochemistry). The proliferation rate is very high, with nearly 100\% of the cells positive for Ki67. D (10x, HE). Soft tissues and nerve fillets of maxillary region with involvement by lymphoid neoplasm

\section{Discussion and conclusion}

According to the International Classification of Headache Disorders (ICHD-3), cluster headache is characterized by the presence of at least five episodes of high-severity pain, most of the time in the orbital region with at least one trigeminal autonomic symptom (Table 1 ). This entity is more frequent in men, and its onset is usually described between 20 and 40 years of age [5]. The likelihood of secondary etiologies increases when the clinical characteristics do not meet the ICHD 3 diagnostic criteria regarding number, duration of episodes, accompanying symptoms, and frequency of attacks or when, despite meeting them, the patient presents an atypical clinical course in addition to an unsatisfactory therapeutic response. When we face this clinical scenario, it is appropriate to take into account criterion $\mathrm{E}$ of the International Classification of Headache, which recommends looking for another entity included in the ICHD-3 that can better explain the signs and symptoms of the patient under study. Although the use of the ICHD-3 criteria has been shown to be useful in

Table 1. ICHD 3 diagnostic criteria for cluster headache [5]

\begin{tabular}{|c|c|}
\hline Criteria & Description \\
\hline A. & At least five attacks fulfilling criteria B-D \\
\hline B. & $\begin{array}{l}\text { Severe or very severe unilateral orbital, supraorbital, and/or temporal pain last- } \\
\text { ing 15-180 minutes (when untreated) }\end{array}$ \\
\hline C. & $\begin{array}{l}\text { Either or both of the following: } \\
\text { (1) at least one of the following symptoms or signs, ipsilateral to the headache: } \\
\text { conjunctival injection and/or lacrimation } \\
\text { nasal congestion and/or rhinorrhea } \\
\text { eyelid edema } \\
\text { forehead and facial sweating } \\
\text { miosis and/or ptosis } \\
\text { (2) a sense of restlessness or agitation }\end{array}$ \\
\hline D. & Occurring with a frequency between one every other day and eight per day \\
\hline E. & Not better accounted for by another ICHD-3 diagnosis \\
\hline
\end{tabular}


the differentiation of primary versus symptomatic etiologies [6], its application in patients with cluster headache of secondary origin has reported accuracy limitations because a significant percentage of these cases may meet the criteria satisfactorily despite demonstrating an underlying etiology [7].

In the reported patient, the criteria $\mathrm{A}-\mathrm{D}$ were satisfactorily met. Additionally, the MRI, MRV, MRA, CT, and CSF studies were found within normal limits. This analysis initially led to consideration of primary etiology; however, due to the absence of therapeutic response and the presence of weight loss and induration sensation in the territory of the submental nerve, systemic etiologies were ruled out.

High-grade B-cell lymphoma represents a subtype of non-Hodgkin lymphoma that affects the central nervous system (CNS) in $5 \%$ of relapses, with a manifestation in the early course of the disease and representing a poor clinical prognostic factor [8].

Numb chin syndrome is characterized by the appearance of sensory symptoms in the territory of the mental nerve, accompanied in some cases by motor symptoms. Although benign etiologies have been described for this syndrome, most of the cases represent the initial symptom of neoplastic diseases [9]. In this case, high-grade B-cell lymphoma was shown, with metastatic lesions in periosteum, jaw region, and right submental nerve, which, due to their size, were not detected in the routine brain images, requiring 18F-FDG-PET, which, due to its ability to detect metabolic changes, has better diagnostic performance compared with conventional neuroimaging. We raised the hypothesis that lesions on the submental nerve can explain the activation of the trigeminovascular system allowing the onset of symptoms that simulate the clinical characteristics suggestive of cluster headache. This model is taken from reports in which head injury can modify neurotransmitters triggering cluster-like symptoms [10]. This hypothesis could be also supported in the control of pain episodes after the nerve resection during the biopsy.

This report highlights the importance of considering neoplastic etiologies with metastases to the cranial nerves as a cause of symptomatic cluster headache. It additionally mentions the need to consider underlying etiologies in the study of cluster headache even when the ICHD-3 criteria regarding number, duration of episodes, and accompanying symptoms are satisfactorily met. Taking into account that the cause of the headache was shown to be related to cranial bone metastasis, this patient can be categorized as secondary headache 11.9 according to the International Classification of Headache.

\section{Clinical implications}

- Although the ICHD 3 criteria in number of episodes, duration of episodes, and accompanying symptoms are met, it is important to consider underlying etiologies, particularly when the clinical course is not as expected.

- It is important to consider neoplastic etiologies with metastases to the cranial nerves as a cause of symptomatic cluster headache.

\section{Abbreviations}

ICHD: International Classification of Headache Disorders; MRI: Magnetic resonance imaging; LP: Lumbar punction; CSF: Cerebrospinal fluid; MRA: Magnetic resonance angiography; MRV: Magnetic resonance venography; FDG-PET: Fluorodeoxyglucose-positron emission tomography.

\section{Acknowledgements}

To Claudia, Isabela, and Antonia.

\section{Authors' contributions}

All authors read and approved the final manuscript, JM-C summarized and analyzed the data and was a major contributor to writing the manuscript. AF-D and AB reviewed the case report and were major contributors to the manuscript. $C$ reviewed the case report and contributed to the analysis of the histopathological samples of the case.

\section{Funding}

The authors received financial support for the translation and publication of this article from Hospital Universitario Mayor Méderi.

Availability of data and materials

Not applicable in this section.

\section{Declarations}

Ethics approval and consent to participate

All information has been appropriately deidentified. This report was approved by Medical Ethic Committee of Rosario University (DVO 1179 CV1252).

\section{Consent for publication}

Written informed consent was obtained from the patient for publication of this case report and any accompanying images. A copy of the written consent is available for review by the Editor-in-Chief of this journal.

\section{Competing interests}

The authors declared no potential conflicts of interest with respect to the research, authorship, and/or publication of this article.

\section{Author details}

${ }^{1}$ Present Address: Departamento de Neurologia, Hospital Univesitario Mayor MEDERI - Universidad del Rosario, Bogotá, Colombia. ${ }^{2}$ Departamento de Neurologia, Clinica Univesitaria Colombia - Keralty, Bogotá, Colombia. ${ }^{3}$ Deparatmento de Medicinia Nuclear - Hospital Univesitario Mayor MEDERI, Universidad del Rosario, Bogotá, Colombia. ${ }^{4}$ Instituto Nacional de Cancerologia - Compensar, Bogotá, Colombia.

Received: 16 December 2020 Accepted: 19 July 2021

Published online: 14 September 2021 


\section{References}

1. Kim J, Lee S, Choi S, Park M, Kim B, Kim M, et al. Spontaneous vertebral artery dissection mimicking cluster headache. Cephalalgia. 2008;28:671-3.

2. Volcy M, Tepper SJ. Cluster-like headache secondary to idiopathic intracranial hypertension. Cephalalgia. 2006;26:883-6.

3. Hannerz J. A case of parasellar meningioma mimicking cluster headache. Cephalalgia. 1989;9:265-9.

4. Branco M, Rodrigues R, Lopes M, Ruano L. Case report cluster-like headache secondary to sphenoid sinus mucocele. Case Rep Neurol Med. 2018. https://doi.org/10.1155/2018/5850286.

5. The International Classification of Headache Disorders, 3rd edition. Cephalalgia. 2018;38(1):1-211.

6. Munoz-Ceron J, Marin-Careaga V, Peña L, Mutis J, Ortiz G. Headache at the emergency room: etiologies, diagnostic usefulness of the ICHD 3 criteria, red and green flags. PLoS ONE. 2019;14(1):e0208728.
7. Edvardsson B. Symptomatic cluster headache : a review of 63 cases. SpringerPlus. 2014;3:1-8.

8. Zahid MF, Khan N, Hashmi SK, Kizilbash SH, Barta SK. Central nervous system prophylaxis in diffuse large B-cell lymphoma. Eur J Haematol. 2016;97:108-20.

9. Lu S, Huang S, Chen Y. Numb chin with mandibular pain or masticatory weakness as indicator for systemic malignancy — a case series study. J Formos Med Assoc. 2017;116:897-906.

10. Lambru G, Castellini P, Manzoni GC, Torelli P. Post-traumatic cluster headache: from the periphery to the central nervous system? Headache. 2009;49:1059-72.

\section{Publisher's Note}

Springer Nature remains neutral with regard to jurisdictional claims in published maps and institutional affiliations.
Ready to submit your research? Choose BMC and benefit from:

- fast, convenient online submission

- thorough peer review by experienced researchers in your field

- rapid publication on acceptance

- support for research data, including large and complex data types

- gold Open Access which fosters wider collaboration and increased citations

- maximum visibility for your research: over $100 \mathrm{M}$ website views per year

At BMC, research is always in progress.

Learn more biomedcentral.com/submissions 